\title{
Biodegradation of 2,6-Naphthalenedisulfonic Acid by a Floc-Forming Bacterium, Pigmentiphaga sp. NDS-1
}

\author{
KINYA UCHIHASHI*, MASAHIRO TAKEO, and SEIJI NEGORO \\ Department of Materials Science and Chemistry, Graduate School of Engineering, \\ Himeji Institute of Technology/2167 Shosha, Himeji, Hyogo 671-2201, Japan
}

\begin{abstract}
Two 2,6-naphthalenedisulfonate (2,6NDS) degrading bacteria were isolated from the activated sludge of a wastewater treatment plant and designated NDS-1 and NDS-2. Only strain NDS-1 showed a floc-forming ability in such media as synthetic wastewater. Sequence analysis of the partial 16S ribosomal DNA (rDNA) sequence of strain NDS-1 revealed that it is a strain closely related to Pigmentiphaga kullae, which was recently established in the family Alcaligenaceae, and that the sequence was in perfect agreement with that of strain NDS-2. Strain NDS-1 could mineralize 2,6NDS and 1,6naphthalenedisulfonate (1,6NDS) with sulfate ion release, but showed no assimilating or desulfonating activity on 8 other sulfonated naphthalenes, indicating that it has a very narrow substrate specificity. 2,6NDS-induced NDS-1 cells exhibited a high oxygen uptake for 2,6NDS, while non-induced cells showed a very low oxygen uptake, demonstrating that 2,6NDS oxidation is inducible in strain NDS-1.
\end{abstract}

Key words: Pigmentiphaga sp., 2,6-naphthalenedisulfonate, floc-forming, desulfonation

List of abbreviations:

NDS: naphthalenedisulfonate,

NS: naphthalenesulfonate,

LB; Luria-Bertani medium,

DOC: dissolved organic carbon,

HPLC; high performance liquid chromatography,

rDNA; ribosomal DNA.

\section{INTRODUCTION}

Sulfonated aromatic compounds are used in large quantities as important intermediates in the synthetic processes of dyes, surfactants, and dispersants. However, they are known to be recalcitrant to biodegradation, because they have $\mathrm{C}-\mathrm{SO}_{3}{ }^{-}$ structures that are not ubiquitous in nature ${ }^{1,2)}$. Therefore, discharge of large amounts of sulfonated aromatic compounds may cause serious environmental pollution.
Indeed, many such compounds have been detected in rivers and seepage from waste dumps $^{3,4)}$.

Of sulfonated aromatic compounds, naphthalenesulfonates (NSs) are the major pollutants in wastewaters from azo-dye producing plants and naphthalene refinery processing plants. It has been reported that 7 to $15 \%$ of the organic pollution of the Rhine river is caused by NSs and their metabolites because they are resistant to biodegradation and are incompletely degraded in conventional sewage plants ${ }^{5}$. Consequently, there have been several studies investigating a way of removing NSs from such wastewaters ${ }^{6-9}$. Ahn et $a l .^{6)}$ reported that, in the practical treatment of naphthalene refinery process wastewater containing mainly 1naphthalenesulfonate (1NS), natural microbial populations and seeded sludge from 
an adjacent plant treating phenolic compounds showed no growth in aeration tanks. Subsequently, they acclimated bacteria from the bottom soil of an open drainage ditch in the naphthalene refinery process and introduced the bacteria into the treatment system, and achieved a good effluent quality. This indicates that the efficiency of treatments for NSs depends on the ability of the NS degrading bacteria.

In order to obtain bacteria with such particular characteristics, several NS degrading bacteria have been isolated and characterized $^{1,2,10-13)}$. However, only a few bacterial strains are able to assimilate naphthalenedisulfonates (NDSs) as the sole carbon source ${ }^{12,13)}$ because NDSs are more resistant to biodegradation than naphthalenemonosulfonates ${ }^{14)}$. Moraxella sp. ASL4 $^{12)}$ and Pseudomonas sp. DS- ${ }^{13)}$ could utilize $1,6 \mathrm{NDS}$ and 2,6NDS as the sole carbon source and a partial degradation pathway for NDSs has been proposed ${ }^{12}$. Desulfonation and partial degradation of NDSs by pure cultures have been also shown $^{10,11}$, but the resulting phenolic metabolites tend to polymerize, bind, and adsorb to solid materials such as clay and humic materials ${ }^{9)}$, and are consequently more persistent to biodegradation.

In this study, we report the isolation and characterization of $2,6 \mathrm{NDS}$ degrading bacteria, one of which has a floc-forming ability that contributes to its survival in biological treatment systems such as activated sludge systems and biofilm systems. In addition, we also show complete degradation (mineralization and desulfonation) of 2,6NDS by this strain.

\section{MATERIALS AND METHODS}

Media, culture conditions Activated sludge was taken from the Wakagawa final wastewater treatment facility (Wakayama, Japan) as a bacterial source. The DS medium containing $3.0 \mathrm{~g}$ of $\mathrm{NH}_{4} \mathrm{Cl}, 1.0 \mathrm{~g}$ of $\mathrm{K}_{2} \mathrm{HPO}_{4}$, $0.25 \mathrm{~g}$ of $\mathrm{KCl}, 0.2 \mathrm{~g}$ of $\mathrm{MgCl}_{2}$, and $0.025 \mathrm{~g}$ of $\mathrm{FeCl}_{3}$, per liter of distilled water was used as a mineral salt medium and Luria-Bertani (LB) medium ${ }^{15)}$ was employed as a nutrient medium. Solid media were prepared by adding $1.5 \%(\mathrm{w} / \mathrm{v})$ agar to liquid media. The isolated bacteria were incubated at $30{ }^{\circ} \mathrm{C}$ on a rotary shaker (120 rpm) unless otherwise stated.

Analytical methods Bacterial growth was monitored by measuring absorbance at $600 \mathrm{~nm}$ (O.D.600) using a HITACHI spectrophotometer U-2000 (HITACHI, Tokyo). When the isolates formed flocs in the culture, protein concentrations was measured instead of O.D.600. This was determined by the method of Lowry-Folin ${ }^{16)}$ after disrupting the cells on ice for $15 \mathrm{~min}$. by ultrasonication at $20 \mathrm{kHz}$ using an ultrasonic disruptor UD-200 (TOMY, Tokyo) and removing the cell debris by centrifugation $\left(18,000 \times g, 1 \mathrm{~h}, 4{ }^{\circ} \mathrm{C}\right)$. Bovine serum albumin was used as the standard. Dissolved organic carbon (DOC) in the culture supernatant was measured by injecting $7 \mu l$ of the supernatant into a total organic carbon analyzer TOC-500 (SHIMADZU, Kyoto) and the $\mathrm{pH}$ of the culture supernatant was measured using a pH meter model F-22 (HORIBA, Kyoto). The concentration of sulfate and sulfite ions in the culture supernatant was determined using the method described by Bertolacini ${ }^{17}$ and the Elman's reagent method $^{18)}$, respectively. The concentration of 2,6NDS in the culture supernatant was determined using a TOSOH HPLC system (pump, CCPS; controller, SC-8020; detector, UV-8020; column oven, CO-8020; column, Mightysil RP -18 GP Aqua 250-4.6 (Kanto Chemical Co., Inc.) $[4.6 \mathrm{~mm}$ I.D. $\times 250 \mathrm{~mm}])$. The analytical conditions were as follows: column temp., $40{ }^{\circ} \mathrm{C}$; flow rate, $0.8 \mathrm{ml} \cdot \mathrm{min}^{-1}$; mobile phase, $50 \mathrm{mM}$ sodium sulfate aqueous solution $^{19)}$; detection wavelength, $254 \mathrm{~nm}$.

\section{Isolation of 2,6NDS degrading bacteria}

Batch enrichment culture for isolation of $2,6 \mathrm{NDS}$ degrading bacteria was started by adding $1 \mathrm{ml}$ of the activated sludge into 100 $\mathrm{m} l$ of DS medium supplemented with yeast extract $\left(200 \mathrm{mg} \cdot l^{-1}\right)$ and $2,6 \mathrm{NDS}\left(100 \mathrm{mg} \cdot l^{-1}\right)$ and shaking the culture. After a week, $10 \mathrm{ml}$ of the culture was centrifuged at $8,000 \times \mathrm{g}$ for $10 \mathrm{~min}$. at $4{ }^{\circ} \mathrm{C}$, the resulting pellet was transferred into the same medium and the culture was incubated under the same conditions. This was repeated to give a total of 14 cultivations, each time lowering the concentration of yeast extract and increasing 
the concentration of $2,6 \mathrm{NDS}$ to give a final $2,6 \mathrm{NDS}$ concentration of $200 \mathrm{mg} \cdot l^{-1}$, and yeast extract concentration of $0 \mathrm{mg} \cdot l^{-1}$. To monitor the degradation of 2,6NDS during the enrichment cultivation, the DOC, $\mathrm{pH}$ and concentration of sulfate ions ${ }^{17)}$ in the culture supernatant were measured as described above. Aliquots of 2,6NDS degrading enrichment culture were spread out onto DS agar plates supplemented with 2,6NDS (100 $\left.\mathrm{mg} \cdot l^{-1}\right)$ as the sole carbon and sulfur source, and the plates were incubated at $30{ }^{\circ} \mathrm{C}$. Colonies which showed good growth on the plates were independently inoculated into $100 \mathrm{ml}$ of DS medium containing 2,6NDS $\left(100 \mathrm{mg} \cdot l^{-1}\right)$ and the culture was incubated for a week. The 2,6NDS degrading ability of each strain was evaluated as described above (DOC and $\mathrm{pH}$ ).

Floc-forming ability The IF (index of flocculation) value $^{20)}$ was employed as an index of floc-forming ability. One milliliter of strain NDS-1 pre-cultured in $50 \mathrm{ml}$ of synthetic wastewater, consisting of $200 \mathrm{mg}$ of meat extract, $300 \mathrm{mg}$ of peptone, $15 \mathrm{mg}$ of $\mathrm{NaCl}, 7.0 \mathrm{mg}$ of $\mathrm{KCl}, 7.0 \mathrm{mg}$ of $\mathrm{CaCl}_{2}, 5.0 \mathrm{mg}$ of $\mathrm{MgSO}_{4}, 105 \mathrm{mg}$ of $\mathrm{NaHCO}_{3}, 330 \mathrm{mg}$ of $2,6 \mathrm{NDS}$ and 1 liter of tap water $(\mathrm{pH} 7.0)$, were inoculated into $100 \mathrm{ml}$ of the same culture, and incubated for 10 days. After standing for $30 \mathrm{~min}$. to settle the flocs, the O.D.600 of the culture without flocs was measured as O.D.sus. Then, the flocs in the culture were disrupted by homogenizing the culture using a homogenizer T25-S2 (IKALABORTECHNIK, Germany) at 9,500 rpm for 10 sec., and the O.D. ${ }_{600}$ of the culture was measured again as $O . D_{\text {.total. }}$ The IF value was calculated as follows:

$\mathrm{IF}(\%)=100 \times($ O.D.total - O.D.sus $) /$ O.D.total

Observation using a scanning electron microscope Floc-forming cells were observed using a scanning electron microscope (SEM). Firstly, floc-forming cells were collected on a cellulose acetate filter (0.2 $\mu \mathrm{m})$, washed twice with sodium phosphate buffer (50 mM, pH 7.2), and then fixed with $2 \%$ glutaraldehyde for $2 \mathrm{~h}$. The cells on the filter were washed with the same buffer and then dehydrated stepwise with various concentrations of ethyl alcohol aqueous solutions $(50-90 \% \mathrm{v} / \mathrm{v})$, with $100 \%$ ethyl alcohol, and finally with $100 \% t$-butyl alcohol. The cells saturated with $t$-butyl alcohol were frozen in a freezer, and then immediately dried using a freeze-drying device JFD-300 (JEOL, Tokyo). The freezedried cells were further sputter-coated with Pt-Pd using an ion sputter model E-1030 (HITACHI), followed by observation using a scanning electron microscope model S-2400 (HITACHI).

Identification of isolated bacteria The isolates were identified according to Bergey's manual of systematic bacteriology, 9th ed. ${ }^{21)}$ In addition, to obtain genetic evidence for the identification, the partial $16 \mathrm{~S}$ ribosomal DNA (rDNA) sequences of the isolates were determined using the method of Rochelle et $a l .^{22)}$ Nucleotide sequencing was performed using a Thermo Sequenase Fluorescent Labelled Primer Cycle Sequencing Kit with 7deaza-dGTP (AMERSHAM PHARMACIA BIOTECH, Tokyo) and a DNA sequencer DSQ -2000L (SHIMADZU, Kyoto) according to the manufacturer's instructions.

2,6NDS degradation test One loop of the isolates was independently inoculated into 50 $\mathrm{ml}$ of DS medium containing 2,6NDS (0.6 $\mathrm{mM}$ ) and each culture was incubated for 3 days. The cells were harvested by centrifugation, washed twice with sodium phosphate buffer $(50 \mathrm{mM}, \mathrm{pH} 7.0)$ and suspended in $4 \mathrm{ml}$ of the same buffer. A 2,6NDS degradation test was started by inoculating $2 \mathrm{ml}$ of the cell suspension into $250 \mathrm{ml}$ of DS medium containing 2,6NDS (0.6 $\mathrm{mM}$ ) and shaking the culture on a rotary shaker. A small amount of the culture was taken at specified time intervals and centrifuged to remove the cells. Finally, the DOC, $\mathrm{pH}$, and concentration of 2,6NDS, sulfate ions ${ }^{17)}$ and sulfite ions ${ }^{18)}$ in the culture supernatant were determined as described above.

Desulfonation test for sulfonated naphthalenes The isolates were inoculated into LB medium containing $2,6 \mathrm{NDS}\left(200 \mathrm{mg} \cdot l^{-1}\right)$ and shaken on a rotary shaker for 3 days. The cells were harvested by centrifugation, washed twice with $50 \mathrm{mM}$ phosphate buffer (pH 7.0), and suspended in an appropriate volume of the same buffer. A small amount (ca. $0.5 \mathrm{ml}$ ) of the cell suspension was 
inoculated into $5 \mathrm{ml}$ of DS medium containing $100 \mathrm{mg} \cdot l^{-1}$ of each sulfonated naphthalene, and the mixture was shaken for 5 days. Then the cells were removed by centrifugation, and the concentration of sulfate ions in the supernatant was determined according to the method described above ${ }^{17}$.

Measurement of oxygen uptake rates for substituted naphthalenes The cell suspensions of the isolates were prepared in the same way as in the 2,6NDS degradation test and kept on ice for $2 \mathrm{~h}$. An oxygen uptake test was started by mixing $1 \mathrm{ml}$ of the cell suspension and $29 \mathrm{ml}$ of a phosphate buffer containing each substituted naphthalene (100 $\left.\mathrm{mg} \cdot l^{-1}\right)$, pre-heated at $30{ }^{\circ} \mathrm{C}$ in a $30-\mathrm{ml}$ special glass chamber. Dissolved oxygen in the mixture was monitored continuously using a dissolved oxygen meter YSI Model 58 and a dissolved oxygen electrode Model 5750 (YELLOW SPRING INSTRUMENTS, U.S.A). The rate of oxygen uptake obtained was corrected for the endogenous respiration rate (rate without any substrate). To determine the amount of protein in the corresponding cell suspension, the cell suspension was sonicated to disrupt the cells, the cell debris was removed by centrifugation, and then protein concentration in the supernatant was determined as described above. The rate was expressed as milligram of dissolved oxygen diminution per gram of protein per min.

Nucleotide sequence accession number

The nucleotide sequence of the partial $16 \mathrm{~S}$ ribosomal DNA of strain NDS-1 was registered in the DDBJ as accession number AB088856.

Chemicals 2,6NDS, naphthalene, 1NS and $2 \mathrm{NS}$ were purchased from Nacalai tesque (Kyoto). 1,5NDS, 2,7NDS, 2hydroxynaphthalene-6-sulfonic acid, 1,3,6naphthalenetrisulfonic acid and 2-hydroxy3,6-naphthalenedisulfonic acid were obtained from Kanto chemicals (Tokyo). 1,6NDS was purchased from Tokyo Chemical Industry (Tokyo). 2-naphthylamine-6-sulfonic acid and 2,6-naphthalenedicarboxylic acid were obtained from Wako Pure Chemical Industries (Tokyo). All of the reagents used were with highest purity available.

\section{RESULTS AND DISCUSSION}

Isolation of 2,6NDS degrading bacteria

In the enrichment batch cultivation, 2,6NDS degrading bacteria were acclimated by lowering the concentration of yeast extract and increasing the concentration of 2,6NDS stepwise for 3 months. Finally, the culture became turbid rapidly with $2,6 \mathrm{NDS}$ as the sole carbon and sulfur source. Figure 1 shows the changes in the concentration of sulfate ions, DOC and $\mathrm{pH}$ in the enriched culture. The DOC value decreased to approx. $15 \%$ of the initial amount in 2 days, proving that enriched bacteria utilized 2,6NDS as the sole carbon source. Corresponding to the decrease in DOC, the concentration of sulfate ions increased rapidly and the $\mathrm{pH}$ value went down gradually. These results mean that a 2,6NDS degrading enrichment culture was established. Then, aliquots of the culture were spread onto DS agar plates supplemented with $2,6 \mathrm{NDS}\left(100 \mathrm{mg} \cdot l^{-1}\right)$ as the sole carbon and sulfur source. About 40 colonies with different shape and color developed on the plates in 5 days. The 2,6NDS degrading ability of each colony was examined in the same DS medium supplemented with 2,6NDS $\left(100 \mathrm{mg} \cdot l^{-1}\right)$. Two strains, designated NDS-1 and NDS-2, showed good growth in the medium and were regarded as $2,6 \mathrm{NDS}$ degrading bacteria. When strain NDS-1 was cultured in LB medium or synthetic wastewater ${ }^{20}$, good flocs were observed in the culture, while strain NDS-2 never formed such flocs under the same culture conditions (see below).

Identification of strain NDS-1 Table 1 summarizes the results of basic taxonomic studies. Strain NDS-1 formed a round, smooth and brownish colony and could grow prototrophically. It was able to utilize a limited number of organic acids, but could not utilize any saccharide tested. From these characteristics, strain NDS-1 was found to have similar morphological and biochemical properties to those of Alcaligenes spp. and Achromobacter spp. (Table 1). Strain NDS-1 grew within a range of $15{ }^{\circ} \mathrm{C}$ to $42{ }^{\circ} \mathrm{C}$ and in a $\mathrm{pH}$ range of 6 to 8 , and the optimal growth temperature and $\mathrm{pH}$ were around $25{ }^{\circ} \mathrm{C}$ and $\mathrm{pH} 7$, respectively. 

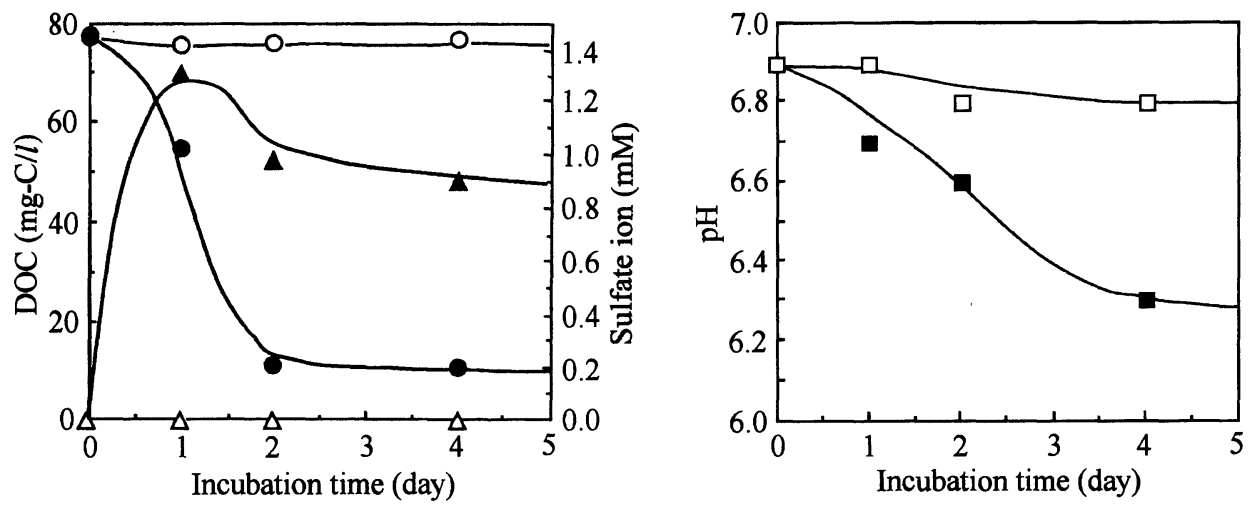

Fig. 1 Change in the concentration of sulfate ions, DOC and $\mathrm{pH}$ in enrichment culture. DS medium containing $200 \mathrm{mg} \cdot \Gamma^{-1}$ of 2,6NDS (2,6NDS-DS medium) was used in this experiment. 2,6NDS -DS medium was incubated with bacteria (enrichment culture) or without bacteria (control). Sulfate ions were measured as described in the text.

Symbols: 1 , DOC (enrichment culture); $\bigcirc$, DOC (control); $\boldsymbol{A}$, sulfate ions (enrichment culture); $\triangle$, sulfate ions (control); $\square, \mathrm{pH}$ (enrichment culture); $\square, \mathrm{pH}$ (control)

The partial nucleotide sequence of the $16 \mathrm{~S}$ rDNA of strain NDS-1 (nt 28-1490) revealed that strain NDS-1 belongs to the $\beta$ subgroup of Proteobacteria. It also showed great similarity to bacterial species in the family Alcaligenaceae: Alcaligenes sp. STC1 [AB046605], $96.6 \%$; Alcaligenes sp. isolate 151 [AJ002802], $96.5 \%$; Achromobacter xylosoxidans strain AU1011 [AF411020], 96.6 \%; Achromobacter xylosoxidans subsp. xylosoxidans [AF411021], $96.6 \%$; Pigmentiphaga kullae strain K24 [AF282916], $99.4 \%$. P. kullae was recently established as a 1-(4'-carboxyphenylazo)-4naphthol degrading bacterium, strain $\mathrm{K} 24^{23)}$ and other species in the Pigmentiphaga genus have not been reported so far. In addition to the highest similarity in the $16 \mathrm{~S}$ rDNA, several nucleotides at positions that distinguish $P$. kullae from other genera in this family were in perfect agreement between strain NDS-1 and $P$. kullae strain K24 (Table 2) ${ }^{23}$. Therefore, we tentatively identified strain NDS-1 as a Pigmentiphaga sp., although there were some differences in the utilization of carbon sources (Table 1).

Interestingly, the $16 \mathrm{~S} \mathrm{rDNA}$ sequence of strain NDS- 1 was in perfect agreement with that of strain NDS-2, and the morphological and biochemical properties of strain NDS-2 were identical to those of strain NDS-1 (data not shown). Therefore, strain NDS-2 seems to be identical except for the floc-forming ability of strain NDS-1.

Floc forming ability of strain NDS-1

Figure 2(a) shows the flocs of strain NDS-1 formed in synthetic wastewater in a test tube. Electron microscopic observation demonstrated that strain NDS-1 produced a filamentous material around the cells [Fig.2(b)], and that the material covered the cells like a net when the cell population increased [Fig.2(c)]. The IF value of strain NDS-1, which was proposed as an index of floc forming ability, was $77.3 \%$ in synthetic wastewater containing $200 \mathrm{mg} \cdot l^{-1}$ of $2,6 \mathrm{NDS}$ and this value was comparable to those of other strong floc-forming bacteria (70-100 \%) reported by Fujita $e t a l{ }^{20)}$ In contrast, the IF value of the non-flocculating strain NDS-2 was less than $2 \%$.

Practical biological treatments for industrial wastewaters are hampered by the slow growth rate of the bacteria used ${ }^{24)}$, fluctuations in pollutant-feed concentrations ${ }^{25)}$, and the presence of high amounts of inorganic compounds and heavy metals ${ }^{26-29)}$. To overcome these problems, immobilized cell techniques and special tanks for culturing the bacterial populations employed have been integrated into practical treatment systems or pilot-plant systems. For instance, in the case of a practical treatment system for 1NScontaining wastewater, a smaller special 
Table 1 Differential characteristics of strain NDS-1 and strains of other genetically similar genera

\begin{tabular}{|c|c|c|c|c|}
\hline 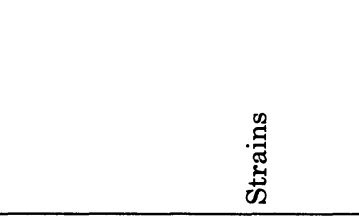 & $\begin{array}{l}\overline{\dot{c}} \\
\text { 之े }\end{array}$ & 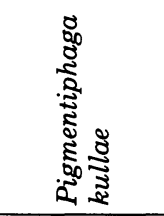 & 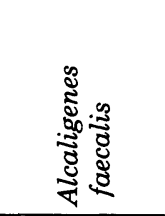 & 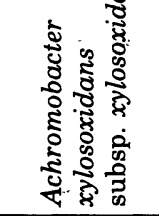 \\
\hline Gram stain & - & - & - & - \\
\hline motility & + & + & + & + \\
\hline shape & $\mathbf{R}$ & $\mathbf{R}$ & $\mathbf{R}$ & $\mathbf{R}$ \\
\hline catalase & + & + & + & + \\
\hline oxidase & + & + & + & + \\
\hline GC content & $68.3 \%$ & $68.5 \%$ & $55.9-59.4 \%$ & $66.0-69.8 \%$ \\
\hline major isoprenoid quinone & $\begin{array}{c}\text { ubiquinone } \\
\text { Q-8 }\end{array}$ & $\begin{array}{c}\text { ubiquinone } \\
\text { Q-8 }\end{array}$ & $\begin{array}{c}\text { ubiquinone } \\
\text { Q-8 }\end{array}$ & $\begin{array}{c}\text { ubiquinone } \\
\text { Q-8 }\end{array}$ \\
\hline Hugh and Leifson test & - & NT & - & NT \\
\hline nitrate reduction to nitrite & - & NT & - & + \\
\hline nitrite reduction & - & NT & + & + \\
\hline gelatin liquefaction & - & NT & - & - \\
\hline arginine hydrolysis & - & NT & - & NT \\
\hline casein hydrolysis & - & NT & - & NT \\
\hline startch hydorolysis & - & NT & - & - \\
\hline urease & - & NT & - & - \\
\hline \multicolumn{5}{|l|}{ Growth at } \\
\hline $4^{\circ} \mathrm{C}$ & - & - & - & - \\
\hline $35^{\circ} \mathrm{C}$ & + & + & + & + \\
\hline $40^{\circ} \mathrm{C}$ & NT & NT & - & + \\
\hline $42^{\circ} \mathrm{C}$ & + & + & NT. & $\mathrm{NT}$ \\
\hline \multicolumn{5}{|l|}{ Utilization of : } \\
\hline L-arabinose & - & - & - & - \\
\hline D-fructose & - & - & - & \pm \\
\hline D-galactose & - & - & - & - \\
\hline D-glucose & - & - & - & + \\
\hline D-mannose & - & - & - & \pm \\
\hline L-rhamnose & - & - & - & - \\
\hline sucrose & - & - & - & - \\
\hline D-xylose & - & - & - & + \\
\hline adonitol & - & - & - & - \\
\hline D-mannitol & - & - & - & - \\
\hline D-raffinose & - & NT & - & - \\
\hline$\beta$-alanine & - & NT & - & \pm \\
\hline oxalate & - & NT & - & - \\
\hline acetate & - & + & + & + \\
\hline propionate & + & + & + & + \\
\hline citrate & + & + & + & + \\
\hline fumarate & + & + & + & + \\
\hline L-glutamate & + & NT & + & + \\
\hline$a$-ketoglutarate & + & NT & \pm & + \\
\hline pyruvate & + & + & \pm & \pm \\
\hline salicylate & + & NT & - & - \\
\hline 3-hydroxybenzoate & + & + & - & - \\
\hline 4-hydroxybenzoate & + & + & - & - \\
\hline iso-valerate & - & NT & \pm & + \\
\hline tartarate & - & NT & - & \pm \\
\hline glycolate & - & NT & + & - \\
\hline succinate & + & NT & + & + \\
\hline DL-malate & + & NT & + & + \\
\hline
\end{tabular}

Symbols : R, rod shape ; NT, not tested 
Table 2 Pattern of selected 16S rRNA signature nucleotides that define genera within the family Alcaligenaceae.

\begin{tabular}{cccccc}
\hline Position(s) $^{\text {a }}$ & NDS-1 & $\begin{array}{c}\text { Pigmentiphaga } \\
\text { kullae K24 }\end{array}$ & Alcaligenes & Achromobacter & Bordetella \\
\hline 43 & C & C & G & G & G \\
123 & C & C & U & U & U \\
238 & G & G & A & A & A \\
399 & G & G & C & C & C \\
412 & A & A & U & U & U \\
1030 & A & A & C & C & C \\
1060 & C & C & U & A & U \\
1197 & G & G & A & U & U \\
1256 & C & C & U & C & C \\
1308 & U & U & G & G \\
1329 & A & A & G & G \\
\hline
\end{tabular}

a) The indicated positions differentiate Pigmentiphaga kullae K24 from the other genera (Alcaligenes, Achromobacter and Bordetella $)^{23)}$. Positions are given relative to the $E$. coli numbering.

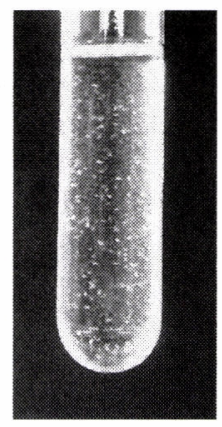

(a)

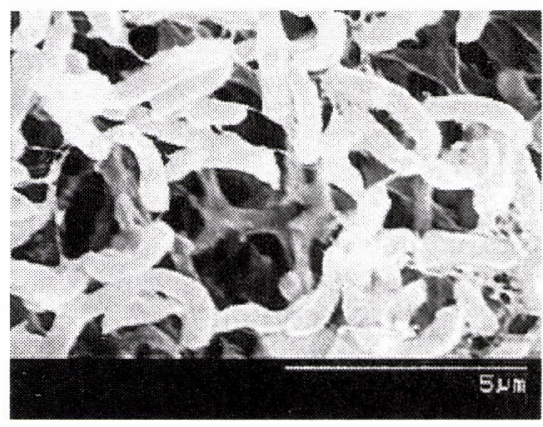

(b)

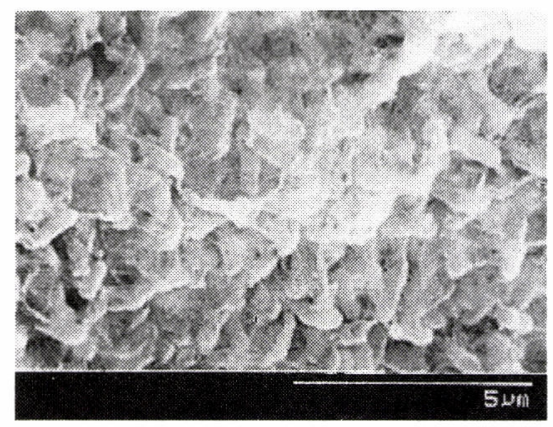

(c)

Fig. 2 (a) The flocs of strain NDS-1 in synthetic wastewater ${ }^{20)}$

(b) Strain NDS-1 observed using a scanning electron microscope

(c) Flocs of strain NDS-1 observed using a scanning electron microscope

aeration tank for the growth of $1 \mathrm{NS}$ degrading bacteria was placed prior to the next two larger aeration tanks to obtain good effluent quality ${ }^{6)}$. In another case, a two stage airlift-loop bioreactor system was employed for the treatment of model wastewater containing various kinds of NSs, where immobilized Pseudomonas testosteroni A3 degraded $1 \mathrm{NS}$ and $2 \mathrm{NS}$ in the first reactor and immobilized strain RK3 mainly removed the more persistent NDSs in the second reactor ${ }^{14)}$. The floc-forming ability of strain NDS-1 may contribute to its survival in biological treatment systems for NSs without the need for such special reactors and immobilized cell techniques. Indeed, its flocforming ability might allow strain NDS-1 to become a stable member in the activated sludge in the Wakagawa final wastewater treatment facility, in spite of its poor utilization of various carbon sources (Table 1).

\section{2,6NDS degradation by strain NDS-1}

Figure 3 shows the changes in concentration of $2,6 \mathrm{NDS}, \mathrm{DOC}$, and protein as an index of growth in the $2,6 \mathrm{NDS}$ degradation test. The concentration of $2,6 \mathrm{NDS}(0.6 \mathrm{mM})$ decreased concomitant with the growth of strain NDS1 , and finally reached $0.14 \mathrm{mM}$ in $120 \mathrm{~h}$. The DOC concentration in the culture also decreased from $68 \mathrm{mg}-\mathrm{C} \cdot l^{-1}$ to $14 \mathrm{mg}-\mathrm{C} \cdot l^{-1}$, indicating that strain NDS- 1 utilizes $2,6 \mathrm{NDS}$ as the sole carbon source. The carbon content in a decrease of $0.46 \mathrm{mM}$ of $2,6 \mathrm{NDS}$ is calculated as ca. $55 \mathrm{mg}-\mathrm{C} \cdot l^{-1}$, which completely corresponds to the decrease in DOC $\left(54 \mathrm{mg}-\mathrm{C} \cdot l^{-1}\right)$. Conversely, the sulfate ion 

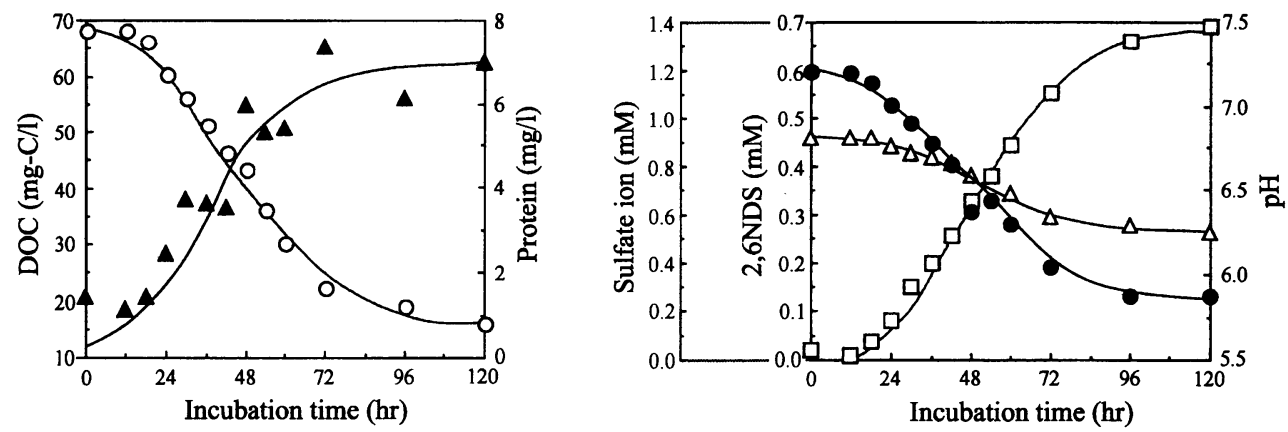

Fig. 3 Degradation of 2,6 NDS by strain NDS-1. A DS medium with 2,6 NDS $\left(200 \mathrm{mg} \cdot \Gamma^{-1}\right)$ as the sole carbon and sulfur source was used in this test. Dissolved organic carbon (DOC) was measured using a TOC analyzer. The concentration of 2,6NDS was measured by HPLC and the concentration of sulfate ions was determined as described in the text. Protein concentration was measured as an index of growth according to the Lowry-Folin method.

Symbols: $\Delta$, Growth (protein); $\bigcirc$, DOC; $, 2,6 N D S ; ~ \square$, sulfate ions; $\Delta, \mathrm{pH}$

concentration increased with the consumption of $2,6 \mathrm{NDS}$, while the $\mathrm{pH}$ in the culture decreased with the increase in sulfate ion concentration. Thus, the decrease in $\mathrm{pH}$ seemed to be caused by sulfate ions liberated into the culture. Sulfite ions could not be detected in the culture supernatant by the method we employed, although Wittich et al. detected a very small amount of sulfite ions (up to ca. $35 \mu \mathrm{M}$ ) in the degradation of excess amounts of 2,6NDS $(10 \mathrm{mM})$ by Moraxella sp. ASL4 ${ }^{12}$. In this test, 2,6NDS was not completely degraded. The residual $2,6 \mathrm{NDS}$ seem to be due to the breakdown of $\mathrm{pH}$, because resting cells in phosphate buffer (pH 7.2) were able to degrade the same concentration of $2,6 \mathrm{NDS}$ completely.

Assimilation and desulfonation range of substituted naphthalenes by strain NDS-1

To determine the assimilation range of substituted naphthalenes by strain NDS-1, an assimilation test of naphthalene and substituted naphthalenes was carried out using DS agarose $\left[\begin{array}{lll}0.8 & \% & \mathrm{w} / \mathrm{v}\end{array}\right]$ plates containing $100 \mathrm{mg} \cdot \mathrm{l}^{-1}$ of each substrate as the sole carbon source. Of 12 substrates tested, strain NDS-1 could grow on only 2,6NDS and 1,6-naphthalenedisulfonate (1,6NDS) (Table 3). Similarly, a desulfonation test of sulfonated naphthalenes was also carried out using the cell suspension of strain NDS-1, and showed that free sulfate ions could be detected only when 2,6NDS and $1,6 \mathrm{NDS}$ were used as the substrate (Table 3 ).
These results indicate that this strain has a very narrow substrate specificity for substituted naphthalenes. Other NDS degrading bacteria, strains ASL4 and DS-1, could also utilize 2,6NDS and 1,6NDS, but not any other NDSs ${ }^{12,13)}$. In contrast, Pseudomonas sp. S-313 was able to desulfonate a wide range of NSs including NDSs, but was unable to utilize any NSs as the sole carbon source ${ }^{11)}$.

Oxygen uptake rates for substituted naphthalenes The oxygen uptake for 2,6 NDS was measured using cells grown on LB medium with or without $2,6 \mathrm{NDS}$ (2,6NDSinduced cells or non-induced cells). There was a high oxygen uptake rate for 2,6NDS (3.33 $\mathrm{mg}-\mathrm{O}_{2} \cdot \mathrm{g}$ of $\operatorname{protein}^{-1} \cdot \mathrm{min}^{-1}$ ) in $2,6 \mathrm{NDS}-$ induced cell cultures, but a very low rate $\left(0.16 \mathrm{mg}-\mathrm{O}_{2} \cdot \mathrm{g}\right.$ of protein $\left.{ }^{-1} \cdot \mathrm{min}^{-1}\right)$ in the noninduced cell cultures. This suggests that 2,6 NDS oxidation in strain NDS- 1 is induced by $2,6 \mathrm{NDS}$. Therefore, oxygen uptake for substituted naphthalenes was investigated using 2,6NDS-induced cells. Table 3 shows the oxygen uptake rates for 11 substituted naphthalenes. The oxygen uptake rates for all of other substrates tested except for $1,6 \mathrm{NDS}$ and 2,7-naphthalenedisulfonate were lower than that for 2,6NDS. These results also support the narrow substrate specificity of strain NDS-1. However, the rate for 2,6-naphthalenedicarboxylate $(2,6$ NDC) was relatively higher than those for other substrates due to its structural similarity to $2,6 \mathrm{NDS}$. Wittich et $a l .{ }^{12)}$ also 
Table 3 Assimilation, desulfonation and oxidation of substituted naphthalene by strain NDS-1.

\begin{tabular}{|c|c|c|c|c|}
\hline Substrate & Assimilation $^{\text {a) }}$ & Desulfonation $^{\text {b) }}$ & $\begin{array}{l}\text { Oxygen Uptake } \\
\left(\mathrm{mg}-\mathrm{O}_{2} \cdot \mathrm{g} \text { of }\right. \\
\text { protein } \\
-1 \\
\left.\min ^{-1}\right)\end{array}$ & $\begin{array}{c}\text { Relative } \\
\text { Activity }^{\mathrm{d})}(\%)\end{array}$ \\
\hline 2,6-naphthalenedisulfonic acid & + & + & 3.33 & 100 \\
\hline Naphthalene ${ }^{\mathrm{e})}$ & - & NT & NT & NT \\
\hline 1-naphthalenesulfonic acid & - & - & 0.29 & 8.8 \\
\hline 2-naphthalenesulfonic acid & - & - & 0.11 & 3.3 \\
\hline 1,5-naphthalenedisulfonic acid & - & - & 0.33 & 9.9 \\
\hline 1,6-naphthalenedisulfonic acid & + & + & 4.00 & 120 \\
\hline 2,7-naphthalenedisulfonic acid & - & - & 3.19 & 96 \\
\hline 2-hydroxy-6-naphthalenesulfonic acid & - & - & 0.19 & 5.7 \\
\hline 2-amino-6-naphthalenesulfonic acid & - & - & 0.32 & 9.7 \\
\hline 2-hydroxy-3,6-naphthalenedisulfonic acid & - & - & 0.39 & 12 \\
\hline 1,3,6-naphthalenetrisulfonic acid & - & - & 0.34 & 10 \\
\hline 2,6-naphthalenedicarboxylic acid & - & NT & 0.54 & 16 \\
\hline
\end{tabular}

a) An assimilation test for naphthalene and substituted naphthalenes was carried out using DS agarose [0.8 \% w/v] plates containing $100 \mathrm{mg} \cdot l^{-1}$ of each substrate as the sole carbon source. Positive $(+)$ shows that strain NDS -1 formed colonies. b) Desulfonation test for sulfonated naphthalenes was carried out using the cell suspension of strain NDS-1. Positive (+) shows that free sulfate ions were detected. c) Oxygen uptake for substituted naphthalenes was investigated using 2,6NDSinduced cells. d) Activity was expressed as the percentage of oxygen uptake rate for 2,6-naphthalenedisulfonic acid. e) Naphthalene was supplied as vapour, putting some crystals on the lid of petri dishes. NT: not tested

reported that the 2,6NDS-grown cells of strain ASL4 co-oxidized its structural analog, $2,6 \mathrm{NDC}$.

The cell extract of strain NDS-1 showed higher oxygen uptake rates for gentisate $\left(0.35 \mathrm{mg}^{-} \mathrm{O}_{2} \cdot \mathrm{g}\right.$ of $\left.\operatorname{protein}^{-1} \cdot \mathrm{min}^{-1}\right)$ and protocatechuate $\left(0.21 \mathrm{mg}^{-} \mathrm{O}_{2} \cdot \mathrm{g}\right.$ of protein ${ }^{-1}$. $\mathrm{min}^{-1}$ ), which are key intermediates in the degradation of aromatic compounds. Moreover, strain NDS-1 could grow on gentisate and protocatechuate in addition to 5sulfosalicylate. Therefore, strain NDS-1 may degrade 2,6NDS through these compounds. An investigation of the degradation pathway of strain NDS- 1 is now in progress.

\section{REFFERENCE}

1 ) Brilon, C., Beckmann, W., Hellwig, M., and Knackmuss, H.-J.: Enrichment and isolation of naphthalenesulfonic acidutilizing Pseudomonads., Appl. Environ. Microbiol., 42, 39-43 (1981)

2 ) Brilon, C., Beckmann, W., and Knackmuss, H.-J.: Catabolism of naphthalenesulfonic acids by Pseudomonas sp. A3 and Pseudomonas sp. C22., Appl. Environ. Microbiol., 42, 44-55 (1981)

3 ) Kim, I. S., Sasinos, F. I., Stephens, R. D., and Brown, M. A.: Anion-exchange chromatography particle beam mass spectrometry for the characterization of aromatic sulfonic acids as the major organic pollutants in leachates from Stringfellow, Califonia, Environ. Sci. Technol., 24, 1832-1836 (1990)

4 ) Lange, F. T., Wenz, M., and Brauch, H.-J.: Trace-level determination of aromatic sulfonates in water by on-line ion-pair extraction/ion-pair chromatography and their behavior in the aquatic environment, J. High Resol. Chromatogr., 18, 243-252 (1995)

5 ) Malle, K. G.: Wie schmutzig ist der Rhein?, Chem. Unserer Zeit, 12, 111-122 (1978)

6 ) Ahn, D.-W., Go, Y.-M., Kim, Y.-J., Shin, H.S., and Lee, J.-K.: Biological treatment of naphthalene refinery wastewater, AROMATIKKUSU (Aromatics), 43, 232237 (1991)

7 ) Wagner, K. and Hempel, D. C.: Kinetic analysis of naphthalenesulfonic acidbiodegradation by immobilized bacteria, World congress III of Chemical Engineering, Tokyo, 1986, Proceedings, Vol. I, 935-937

8 ) Wagner, K. and Hempel, D. C.: Bio- 
degradation by immobilized bacteria in an airlift-loop reactor-Influence of biofilm diffusion limitation, Biotechnol. Bioeng., 31, 559-566 (1988)

9 ) Ruff, J., Hitzler T., Rein, U., Ritter, A., and Cook, A. M.: Bioavailability of waterpolluting sulfonoaromatic compounds, Appl. Microbiol. Biotechnol., 52, 446-450 (1999)

10) Nörtemann, B., Baumgarten, J., Rast, H. G., and Knackmuss, H.-J.: Bacterial communities degrading amino- and hydroxynaphthalene-2-sulfonates., Appl. Environ. Microbiol., 52, 1195-1202 (1986)

11) Zürrer, D., Cook, A. M., and Leisinger, T.: Microbial desulfonation of substituted naphthalenesulfonic acids and benzenesulfonic acids., Appl. Environ. Microbiol., 53, 1459-1463 (1987)

12) Wittich, R. M., Rast, H. G., and Knackmuss, H.-J.: Degradation of naphthalene-2,6- and naphthalene-1,6disulfonic acid by a Moraxella sp., Appl. Environ. Microbiol., 54, 1842-1847 (1988)

13) Ohe, T. and Watanabe, Y.: Microbial Degradation of $1,6^{-}$and $2,6^{-}$ naphthalenedisulfonic acid by Pseudomonas sp. DS-1., Agric. Biol. Chem., 52, 2409-2414 (1988)

14) Krull, R. and Hempel, D. C.: Biodegradation of naphthalenesulphonic acid-containing sewages in a two-stage treatment plant, Bioprocess Eng., 10, 229 -234 (1994)

15) Sambrook, J., Fritsch, E. F., and Maniatis, T.: Molecular cloning, a laboratory manual, 2nd ed. Cold Spring Harbor Laboratory Press, New York (1989)

16) Lowry, O. H., Rosebrough, N. J., Farr, A. L., and Randall, R. J.: Protein measurement with the Folin phenol reagent, J. Biol. Chem., 193, 265-275 (1951)

17) Bertolacini, R. J. and Barney, J. E.: Colorimetric determination of sulfate with barium chloranilate., Anal. Chem., 29, 281-283 (1957)

18) Johnston, J. B., Murray, K., and Cain, R. B.: Microbial metabolism of aryl sulfonates: a reassessment of colorimetric methods for the determination of sulphite and their use in measuring desulphonation of aryl and alkylbenzene sulphonates. Antonie van Leeuwenhoek, J. Microbiol. Serol., 41, 493-511 (1975)

19) Jandera, P. and Churáček, J.: Reversedphase liquid chromatography of aromatic sulphonic acids and other strongly polar compounds without addition of an ionpairing counter-ion, J. Chromatogr., 197, 181-187 (1980)

20) Fujita, M., Ike, M., Nakamura, F., and Soda, S.: Isolation and characterization of a floc-forming bacterium Sphingomonas paucimobilis 551 from actvated sludge, Japanese J. Wat. Treat. Biol., 34, 195204 (1998)

21) Kersters, K., Ley, J. D., and Pittman, M.: Bergey's manual of systematic bacteriology, Vol. 1, Krieg, N. R., Holt, J. G. (ed.), p. 361-373, 388-393, 9th ed. Williams \& Wilkins, Boltimore (1989)

22) Rochelle, P. A., Will, J. A. K., Fry, J. C., Jenkins, G. J. S., Parkes, R. J., Turley, C. M., and Weightman, A. J.: Extraction and amplification of 16S rRNA genes from deep marine sediments and seawater to assess bacterial community diversity. In Trevors J. T. and van Elsas, J. D. (ed.), Nucleic Acids in the Environment, pp. 219 -239. Springer-Verlag, New York (1995).

23) Blümel, S., Mark, B., Busse, H.-J., Kämpfer, P., and Stolz, A.: Pigmentiphaga kullae gen. nov., sp. nov., a novel member of the family Alcaligenaceae with the ability to decolorize azo dyes aerobically, Int. J. Syst. Evol. Microbiol., 51, 1867-1871 (2001)

24) Nötemann, B. and Hempel, D. C.: Application of adapted bacterial cultures for the degradation of the xenobiotics compounds in industrial waste-waters. In: Martin, A. M. (ed.): Biological degradation of waters; pp. 261-279; London-New York; Elsevier science publ. Ltd.; 1991

25) Hüppe, P., Höke, H., and Hempel, D. C.: Biological treatment of effluents from a coal tar refinery using immobilized biomass., Chem. Eng. Technol., 13, 73-79 (1990)

26) Gerdes-Kühn, M. and Hempel, D. C.: Biologische schwermetallabtrennung aus 
industriellen abwässern., Entsorgungs Praxis, 11, 719-725 (1991)

27) Gerdes-Kühn, M., Rudolph, E., Nörtemann, B., and Hempel, D. C.: Influence of heavy metal ions on the biodegradation of xenobiotic compounds., 4th World Congress of Chemical Engineering Karlsruhe, Preprints I 3.615 (1991)

28) Lobas, D., Gerdes-Kühn, M., and Hempel, D. C.: Wirkung von Salzlasten auf den bakteriellen Abbau von xenobiotischen Abwasserinhaltsstoffen., Korrespondenz
Abwasser, 38, 1362-1372 (1991)

29) Rudolph, E. and Hempel, D. C.: Einfluß von Schwermetallen auf immobilisierte Bakterienkulturen. In: GVC-VDIGesellschaft Verfahrenstechnik und Chemieingenieurwesen (eds.):

Verfahrenstechnik der mechanischen, thermischen, chemischen und biologischen Abwasserbe-handlung, 2. GVC-Kongreß, Würzburg, Preprins Band 2-Poster PD-8 pp.219-223 (1992)

(Submitted 2002. 8. 8) (Accepted 2002. 9. 17) 